\title{
The Effect of Sugar Beet Broadleaf Herbicides on Fluorescence Induction Curves in Amaranthus retroflexus $\mathrm{L}$. and Portulaca oleracea $\mathrm{L}$.
}

\author{
Ali Asghar CHITBAND ${ }^{1 *}$, Reza GHORBANI ${ }^{2}$, \\ Mohammad Hassan RASHED MOHASSEL ${ }^{2}$, Mahbubeh NABIZADE ${ }^{3}$
}

\author{
${ }^{1}$ Lorestan University, Faculty of Agriculture, Department of Plant Protection, Khorramabad, \\ Iran;a.a.chitband@gmail.com (*correspondingauthor) \\ ${ }^{2}$ Ferdowsi University of Mashhad, Faculty of Agriculture, Department of Agronomy, Iran \\ ${ }^{3}$ Master of Weed Science, Mashhad, Iran
}

\begin{abstract}
Chlorophyll fluorescence analysis is a simple and rapid method for detecting herbicide effects after a short time following their application in photosynthetic apparatus in plants. Chlorophyll fluorescence measurements were carried out against two broad of weeds to describe how the Kautsky curve and its parameters were affected by herbicides. Desmedipham + phenmedipham + ethofumesate changed the chlorophyll fluorescence induction curve at all time intervals except four hours after spring (HAS) in Amaranthus retroflexus L. and at all doses of Portulaca oleracea L. 4 HAS. In contrast, chlorophyll fluorescence inhibition was evident by chloridazon at doses of 650 and $325 \mathrm{~g}$ a.i. ha ${ }^{-1}$ in $P$. oleracea and $A$. retroflexus respectively, for all time intervals. Furthermore, chlorophyll fluorescence decays only occurred by clopyralid in $A$. retroflexus at the highest dose. A biomass effective dose $\left(\mathrm{ED}_{50}\right.$ and/or $\left.\mathrm{ED}_{90}\right)$ based on log-logistic dose-response curves for $A$. retroflexus were considerably higher than that of $P$. oleracea. The maximum quantum efficiency $\left(\mathrm{F}_{\mathrm{V}} / \mathrm{F}_{\mathrm{m}}\right)$ was stable, whereas the relative changes at the $J$ step $\left(F_{v j}\right)$ and area (the area between the Kautsky curve and the maximum fluorescence $\left(F_{m}\right)$ ) was more sensitive to all three herbicides. There was a relatively good correlation between fluorescence parameters taken 24 hours after the spraying and the dry matter taken three weeks later, for both species under study.
\end{abstract}

Keywords: dose-response curve, effective dose, growth stage, PSII inhibitors, reduce herbicide dose

\section{Introduction}

Light energy absorbed by leaf chlorophyll molecules, if not used in a photosynthetic pathway, is dissipated as heat or re-emitted as fluorescence. These three processes take place in competition, and any rise in the efficiency of one will result in a decline in the yield of others (Maxwel and Johnson, 2000). Even though the total amount of chlorophyll fluorescence is quite low $(2-10 \%$ of the absorbed light) (Govindjee, 1995), the chlorophyll fluorescence is known as an open window in the heart of the photosynthesis process in plants due to its intricate connection with photosynthesis of various processes. In fact, the changes in photosynthetic function are reflected in changes in the chlorophyll fluorescence (Papageorgiou and Govindjee, 2004).
The spectrum of fluorescence wavelength may compare with that of the absorbed light. Hence, the yield of fluorescence can be quantified by exposing a leaf to the light of a defined wavelength and measuring the amount of the light re-emitted at longer wavelengths. The fluorescence induction curve (Kautsky curve) has two phases in higher plants including a slow decreasing phase (within a few minutes) and a fast increasing phase (within a second). The slow phase is known as a transient fluorescence (PSMT) (Holub et al., 2007) and the fast phase is called OJIP (Boisvert et al., 2006). An increase in the amounts of chlorophyll fluorescence emission is created with an illumination of $650 \mathrm{~nm}$ wavelength of healthy dark-adapted leaves with some trait phases. These phases primarily indicate photochemical events relevant to PSII (Govindjee, 1995). Three phases are found discovered on the O, J, I and $\mathrm{P}$ steps and depicted as follows: The O-J phase, complete reduction of the primary electron acceptor $\mathrm{Q}_{\mathrm{A}}$ of PSII

Received: 12 Jul 2017. Received in revised form: 21 Sep 2017. Accepted: Sep 2017. Published online: 30 Sep 2017. 
434

occurs from $50 \mu \mathrm{s}$ to $2 \mathrm{~ms}$, the J-I phase corresponds to electron transfers from $\mathrm{Q}_{A}$ to $\mathrm{Q}_{B}$ between 2 and $30 \mathrm{~ms}$ and the I-P phase corresponds to the release of fluorescence quenching by the oxidized plastoquinone pool taking place within 30-500 ms (Srivastava et al., 1999; Appenroth et al., 2000; Boisvert et al., 2006) (Fig. 1).

The fluorescence technique is fluorescence induction or the measurement of changes in fluorescence yield when a light is abruptly turned on after a dark period. Upon illumination, fluorescence of leaves adapted to darkness increases from the ground-state value $\left(\mathrm{F}_{0}\right)$ to its maximum value $\left(\mathrm{F}_{\mathrm{m}}\right)$ within a second. Under this condition, $\mathrm{Q}_{\mathrm{A}}$, the first electron acceptor of PSII, is fully reduced. This allows the determination of the maximum quantum efficiency of the PSII primary photochemistry (often the ratio of socalled variable fluorescence), given by $F_{v}\left[F_{v}=\left(F_{m}-F_{0}\right) / F_{m}\right]$ (Strasser and Govindjee, 1992) (Fig. 1). Apart from the plant species with unstressed leaves, the $\mathrm{F}_{\mathrm{v}} / \mathrm{F}_{\mathrm{m}}$ value is close to 0.83 . A lower value indicates that a proportion of PSII reaction centre is damaged, a phenomenon called photoinhibition, often observed in plants under stress conditions (Kim et al., 1999; Hess, 2000; Misra et al., 2001; Thach and Truong, 2016).

The polyphasic Kautsky transient curve was measured to evaluate the effects of herbicides on the photochemical efficiency of PSII (Juneau et al., 2007; Balabanova et al., 2016). Desmedipham, phenmedipham and chloridazon as photosystem II (PSII) inhibitors cause the blocking of electron transfer between the primary and secondary quinones $\left(\mathrm{Q}_{\mathrm{A}}\right.$ and $\left.\mathrm{Q}_{B}\right)$ of PSII by binding to the $\mathrm{Q}_{B}$-binding site and accepting electrons from $\mathrm{Q}_{\mathrm{A}}$ in the chloroplasts (Strasser and Govindjee, 1992; Hess, 2000; Zhang et al., 2014). Followed by the interruption in the photosynthetic electron transport chain, the concomitant inhibition of ATP production and carbon fixation occur (Kohno et al., 2000; Hess, 2000). Consequently, plant death happens by light- induced oxidative stress, i.e. by the formation of reactive oxygen species (ROS) near the PSII reaction centres, leading to the breaking of the protein-pigment complexes, lipid peroxidation and proteolysis of PSII as well as the plant death (Hess, 2000; Luo et al., 2004). In

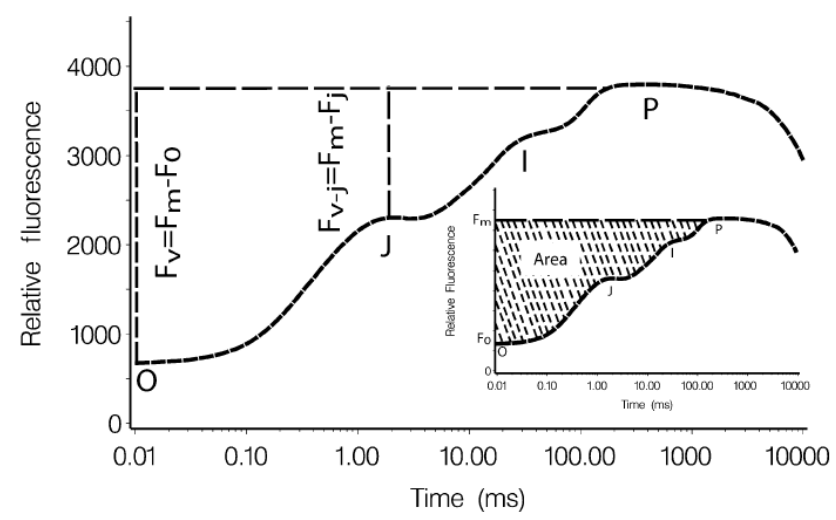

Fig. 1. Kautsky curve recorded with Handy PEA instrument in a 30 minutes dark adapted leaf. The Kautsky curve rise from O to P levels is characterized by the OJIP steps reflecting PSII electron transport from water to PQ pool (Abbaspoor and Streibig, 2005). addition, photosynthesis is not the primary target site of the growth regulator herbicides (PGR) such as clopyralid and ethofumesate as fatty acid biosynthesis inhibitors, but changes in chlorophyll fluorescence induction curve responses were formerly observed in treated plants (Percival and Baker, 1991; Christensen et al., 2003; Abbaspoor and Streibig, 2005). Barbagallo et al. (2003) found early effects on the shape of the Kautsky curve and derived fluorescence parameters of Arabidopsis thaliana seedlings by asulam, bifenox, 2,4-D, diclofop-methyl, glyphosate and imazapyr which do not have a direct impact on photosynthesis.

The main goals of this study were to determine how rapidly the three herbicides with different modes of action affect the shape of the Kautsky curve and relevant parameters (the operation of the photosynthetic apparatus) in $A$. retroflexus and $P$. oleracea, and whether the above mentioned herbicide variation affects the shape of the Kautsky curve in a time course study of these weeds. The final objective was to relate various fluorescence parameters, derived from the Kautsky curve, to the dry matter of these herbicides.

\section{Materials and Methods}

\section{Plantmaterials}

The seeds of Amaranthus retroflexus L. and Portulaca oleracea L. were collected from plants in the experimental station of the Faculty of Agriculture, Ferdowsi University of Mashhad, Mashhad, Iran, and stored in a refrigerator (at $3 \pm$ $\left.1^{\circ} \mathrm{C}\right)$ until use. Bioassays were conducted between June 2015 and September 2015 at the faculty greenhouse. To increase the seed germination of $A$. retroflexus before starting the experiment, the seeds were placed in $\mathrm{H}_{2} \mathrm{SO}_{4}(98 \%)$ for two minutes and then washed according to Andersen (1968). The seeds of $P$. oleracea did not have any dormancy. Twenty seeds were sown at depth of $0.5 \mathrm{~cm}$ in $2 \mathrm{~L}$ plastic pots filled with a mixture of sand, clay loam soil, and peat $(1: 1: 1 \mathrm{v} / \mathrm{v})$. The pots were placed in a controlled environment under greenhouse conditions with photoperiod of $16 / 8 \mathrm{~h}$ (day/night) for the light/dark condition and temperatures of $15 \pm 4^{\circ} \mathrm{C}$ at night and $25 \pm 6^{\circ} \mathrm{C}$ during the day. An illumination of 2,250 lux was obtained from $400 \mathrm{~W}$ high-pressure sodium vapour lamps (Osram Sylvania, Lynn, MA, USA). Plants were thinned to four per pot at the one- and two-true leaf stages. After thinning, the pots were fertilized with $20 \mathrm{ml}$ of a watersoluble N:P:K (20:20:20) fertilizer, at a concentration of $3 \mathrm{~g}$ of fertilizer per litre of tap water. The pots were irrigated every three days with tap water.

\section{Treatments and chemical}

Two independent dose-responsive experiments for $A$. retroflexus and $P$. oleracea were simultaneously conducted for three herbicides. The experiments were replicated twice and obtained similar results. Since the results of the two replicates were almost the same, the results of one of them are being reported. The treatments included of eight doses of the following herbicides: (i) desmedipham + phenmedipham + ethofumesate (Betanal Progress- OF, $274 \mathrm{mg} \mathrm{L}^{-1}$, Bayer Crop Science) at $0,51.38,102.75,205.5,308.25,411,616.5$ and $822 \mathrm{mg}$ a.i. ha ${ }^{-1}$, (ii) chloridazon (Pyramin, $650 \mathrm{~g} \mathrm{~L}^{-1}$, BASF $\mathrm{A} / \mathrm{S}$ ) at $0,81.25,162.5,325,650,1300,1950$ and $2600 \mathrm{~g}$ a.i. 
$\mathrm{ha}^{-1}$, and (iii) clopyralid (Lontrel $300 \mathrm{mg} \mathrm{L}^{-1}$, Golsam Gorgan Chemicals Corporation, Gorgan, Iran) with doses: 0, 15, 30, $60,90,120,180$ and $240 \mathrm{mg}$ a.i. $\mathrm{ha}^{-1}$. For each herbicide, the experiment was arranged in a completely randomized design with four replications. The plants were sprayed at the four- to six-true leaf stage by using an overhead trolley sprayer (Matabi 121030 Super Agro 20 L sprayer; Agratech Services-Crop Spraying Equipment, Rossendale, UK), equipped with an 8002 flat fan nozzle tip delivering $200 \mathrm{~L} \mathrm{ha}^{-1}$ at 2 bar spray pressure.

\section{Chlorophyll fluorescence assays}

Chlorophyll fluorescence measurements were carried out on dark-adapted leaves at the same stages of development among pots. Fluorescence emissions were measured using a portable chlorophyll fluorometer (Handy-PEA; Hansatech Instruments, King's Lynn, Norfolk, UK), which emits light of $650 \mathrm{~nm}$ wavelength with an intensity of 3,000 $\mu \mathrm{mol}$ photons $\mathrm{m}^{-2} \mathrm{~s}^{-1}$ for $10 \mathrm{~s}$.

The leaves were adapted to darkness for a minimum of 30 min prior to measurement. The fluorescence measurements were taken 4 hours after spraying (HAS) for A. retroflexus and $P$. oleracea and again at 24, 48, 72 and 168 HAS. The Kautsky curves were visually examined for the effects of time and the dose (Rodriguez and Strasser, 2002) by the BIOLYZER programme with the OJIP steps as the fixed points. The most important parameters derived from the Kautsky curve were: (i) $\mathrm{F}_{\mathrm{V}} / \mathrm{F}_{\mathrm{m}}$ or the maximum quantum efficiency of PSII $\left(\mathrm{F}_{\mathrm{v}} / \mathrm{F}_{\mathrm{m}}=\left(\mathrm{F}_{\mathrm{m}}-\mathrm{F}_{\mathrm{o}}\right) / \mathrm{F}_{\mathrm{m}}\right)$; (ii) $\mathrm{F}_{\mathrm{v}_{j}}$ or the relative changes at the $J$ step $\left(F_{v j}=\left(F_{m}-F_{j}\right) / F_{m}\right)$; where $F_{m}$ is the maximum fluorescence, $F_{0}$ is the ground state fluorescence and $\mathrm{F}_{\mathrm{j}}$ is fluorescence at $\mathrm{J}$ step and (iii) area (area between fluorescence curve and Fm). Three weeks after treatment (WAT), the biomass of the experimental units (all of plants in each pot) was harvested and oven dried at $75^{\circ} \mathrm{C}$ for $48 \mathrm{~h}$ and then weighed.

\section{Statistical analysis}

A preliminary analysis of the dose-response curves showed that the data were best fitted with a three-parameter asymmetric log-logistic model against the dose with the lower limit of zero (Seefeldt et al., 1995):

$$
U=\frac{d}{1+\exp [b(\log (z)-\log (E D 50))]}
$$

Where $\mathrm{U}$ is biomass production at dose $\mathrm{z}, \mathrm{d}$ is the upper limit where the dose is zero, ED50 denotes the required dose of herbicide for giving $50 \% \mathrm{~A}$. retroflexus and $P$. oleracea control, and $\mathrm{b}$ is the slope of the regression line around the inflection point of the curve, denoted by ED50. The ED50 parameter can be replaced by any ED level (e.g. the ED90). The ED90 denotes the required dose of herbicide to give $90 \%$ A. retroflexus and $P$. oleracea control. The goodness-of-fit was assessed by graphical analyses of the residuals and the tests for the lack of fit of the models. In order to stabilize the variance, a Box-Cox transformation technique was used (Streibig et al., 1993). An analysis of the dose-response curves was conducted by RStudio graphical medium of $\mathrm{R}$ software and the add-on package drc described elsewhere (Ritz and Streibig, 2012).

Based on the available information, the ED50A
(ED90A) and ED50B (ED90B) are the ED50 or ED90 of herbicide A (PSII inhibitor herbicides) and herbicide B (Clopyralid), respectively. The relative potency (RP) value was used to describe horizontal displacement between the two response-dose curves:

$$
R P=\frac{E D_{50 A} o r E D_{90 A}}{E D_{50 B} o r E D_{90 B}}
$$

The relative potency between herbicides $\mathrm{A}$ and $\mathrm{B}$ expresses the biological exchange rate between herbicides when applied separately (Streibig et al., 1993).

\section{Results}

\section{Dose-response studies}

The dose-response curve regressions for the two experiments for dry weight of $A$. retroflexus and $P$. oleracea are shown in Table 1. In both experiments, the test for the lack of fit was not significant, indicating that the logistic model was able to describe the data as well as an ordinary ANOVA. The relative potency between treatments is approved by the differences of the two experiments. These differences in $\mathrm{ED}_{50}$ or $\mathrm{ED}_{90}$ and relative potency $\left[\mathrm{ED}_{50}\right.$ (desmedipham + phenmedipham + ethofumesate)/ $\mathrm{ED}_{50}$ (chloridazon)] differed nearly threefold in each experiment (Table 1). In both experiments, the $\mathrm{ED}_{50}$ and $\mathrm{ED}_{90}$ values of desmedipham + phenmedipham + ethofumesate were lower than chloridazon and clopyralid for A. retroflexus and $P$. oleracea at the cotyledon stage revealed that desmedipham + phenmedipham + ethofumesate were potent compared to other herbicides. However, herbicides application showed that a higher dose was also required for $50 \%$ or $90 \%$ reduction in the entire dry weight for $A$. retroflexus (Table 1). Consequently, we may recommend using desmedipham + phenmedipham + ethofumesate, which may show a better performance for weed control in sugar beet instead of chloridazon and clopyralid.

\section{Chlorophyll fluorescence studies \\ The Kautsky curves}

The results of the first experiment showed that Kautsky curves with distinctive OJIP steps were irreversibly turned to straight lines by desmedipham + phenmedipham + ethofumesate $4 \mathrm{HAS}$ at a dose of $308.25 \mathrm{mg}$ ai ha $^{-1}$ up to the highest and to the first dose $\left(51.38 \mathrm{mg}\right.$ a.i. $\left.\mathrm{ha}^{-1}\right)$ for other time course of florescence measurement i.e. 24, 48, 72 and 168 HAS in A. retroflexus (Fig. 2a). Chloridazon had no impact on the reduction of $A$. retroflexus florescence at the first doses of 81.25 and $162.5 \mathrm{~g}$ a.i. ha ${ }^{-1}$ for all time studies of florescence measurement compared with control treatment, but at doses of $325 \mathrm{~g}$ a.i. ha ${ }^{-1}$ up to the 2,600 g a.i. ha ${ }^{-1}$, the shape of the Kautsky curve was entirely changed. Clopyralid did not much affect the Kautsky curves at any of the applied doses except $240 \mathrm{mg}$ a.i. ha ${ }^{-1}$ compared to the control treatment, but the use of this dose in $A$. retroflexus, resulted in the shape of the Kautsky curves being influenced by clopyralid, a PGR inhibitor (Fig. 2g).

In $P$. oleracea, the application of desmedipham + phenmedipham + ethofumesate affected the shape of the Kautsky curve for all doses of $4 \mathrm{HAS}$ (Fig. 2b). The Kautsky curves with distinctive OJIP steps were irreversibly changed 
Table 1. Summary of dose-response analysis of dry matter at 21 days after treatment (DAT) (four to six true leaf stage) for both of experiments. In both experiments the test for lack of fit were not significant, indicating that the logistic model was able to describe the data better than an ordinary ANOVA

\begin{tabular}{|c|c|c|c|c|c|c|c|c|c|}
\hline \multirow{2}{*}{ Weed species } & \multirow{2}{*}{ Herbicide } & \multirow{2}{*}{$\begin{array}{l}\text { Upper limit } \\
(\mathrm{SE})^{\mathrm{a}}\end{array}$} & \multirow{2}{*}{ Slope (SE) } & \multirow{2}{*}{$\mathrm{ED}_{50}(\mathrm{SE})^{\mathrm{b}}$} & \multirow{2}{*}{$\mathrm{ED}_{90}(\mathrm{SE})$} & \multirow{2}{*}{$\mathrm{F}_{\mathrm{vj}}$} & \multirow{2}{*}{$\begin{array}{c}\text { Lack of fit } \\
\text { test }(5 \%)\end{array}$} & \multicolumn{2}{|c|}{ Relative potency (RP) } \\
\hline & & & & & & & & $\mathrm{ED}_{50}(\mathrm{SE})$ & $\mathrm{ED}_{90}(\mathrm{SE})$ \\
\hline \multicolumn{10}{|l|}{$\begin{array}{c}\text { First } \\
\text { experiment }\end{array}$} \\
\hline $\begin{array}{l}\text { Redroot } \\
\text { pigweed }\end{array}$ & $\begin{array}{c}\text { Desmedipham + } \\
\text { phenmedipham } \\
+ \\
\text { ethofumesate }\end{array}$ & $4.66( \pm 0.70)$ & $1.44( \pm 0.04)$ & $75.56( \pm 11.05)$ & $343.96( \pm 29.84)$ & $98.24( \pm 15.21)$ & $0.78(\mathrm{NS})^{\mathrm{c}}$ & $3.83( \pm 0.96)$ & $2.51( \pm 0.84)$ \\
\hline \multicolumn{10}{|l|}{$\begin{array}{l}\text { (Amaranthus } \\
\text { retroflexus } \mathrm{L} \text {.) }\end{array}$} \\
\hline \multirow{2}{*}{ (AMARE) } & Chloridazon & $4.24( \pm 0.61)$ & $1.22( \pm 0.04)$ & $201.58( \pm 21.92)$ & $1215.74( \pm 125.65)$ & $582.35( \pm 55.41)$ & $0.89(\mathrm{NS})$ & $10.21( \pm 2.83)$ & $8.86( \pm 2.01)$ \\
\hline & Clopyralid & $3.94( \pm 0.48)$ & $1.13( \pm 0.03)$ & $19.74( \pm 2.59)$ & $137.29( \pm 12.04)$ & $41.19( \pm 5.21)$ & $0.22(\mathrm{NS})$ & & \\
\hline \multicolumn{10}{|l|}{$\begin{array}{c}\text { Second } \\
\text { experiment }\end{array}$} \\
\hline $\begin{array}{l}\text { Common } \\
\text { purslane }\end{array}$ & $\begin{array}{c}\text { Desmedipham + } \\
\text { phenmedipham } \\
+ \\
\text { ethofumesate }\end{array}$ & $2.55( \pm 0.06)$ & $1.03( \pm 0.03)$ & $35.08( \pm 4.29)$ & $299.22( \pm 27.39)$ & $79.22( \pm 13.48)$ & $0.48(\mathrm{NS})$ & $1.87( \pm 0.28)$ & $2.31( \pm 0.59)$ \\
\hline \multirow{2}{*}{\multicolumn{10}{|c|}{$\begin{array}{l}\text { (Portulaca } \\
\text { oleracea L.) }\end{array}$}} \\
\hline & & & & & & & & & \\
\hline \multirow{2}{*}{ (POROL) } & Chloridazon & $2.83( \pm 0.07)$ & $1.19( \pm 0.05)$ & $187.67( \pm 16.68)$ & $1138.31( \pm 107.67)$ & $409.94( \pm 43.73)$ & 0.98 (NS) & $10.03( \pm 2.57)$ & $8.79( \pm 1.27)$ \\
\hline & Clopyralid & $2.66( \pm 0.06)$ & $1.13( \pm 0.04)$ & $18.72( \pm 2.29)$ & $129.44( \pm 11.59)$ & $34.28( \pm 4.02)$ & 0.57 (NS) & & \\
\hline
\end{tabular}

${ }^{2}$ Standard Error, ${ }^{\mathrm{b}} \mathrm{ED}_{50}$ or $\mathrm{ED}_{90}=$ Effective Dose at 50 or 90 percent, ${ }^{\mathrm{c}} \mathrm{NS}$ : not significant at the $5 \%$ level, Abbreviations: AMARE, Amaranthus retroflexus L. (Redroot pigweed); POROL, Portulaca oleracea L. (Common purslane)

a)

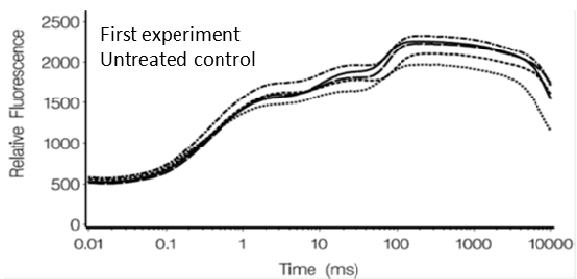

c)

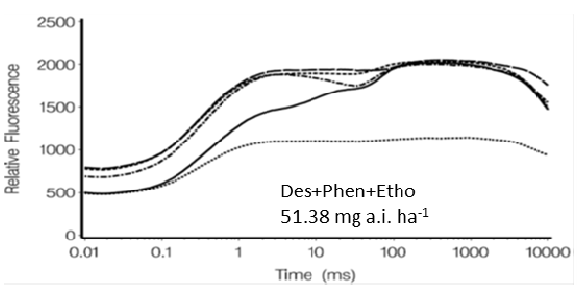

e)

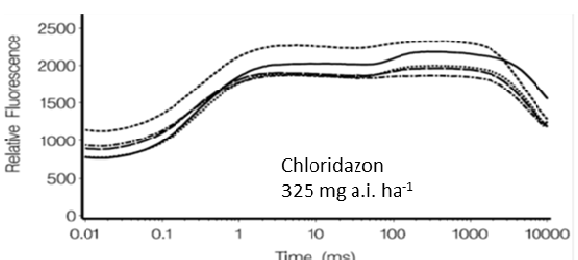

g)

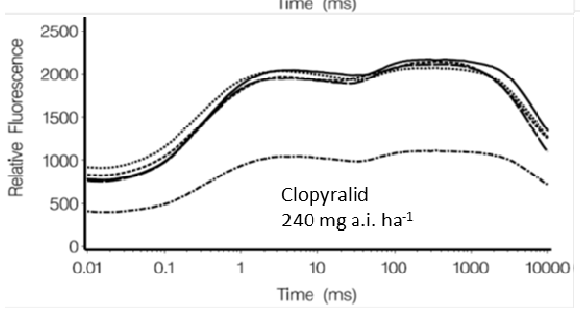

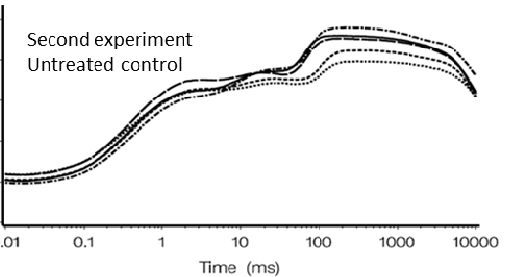

b)
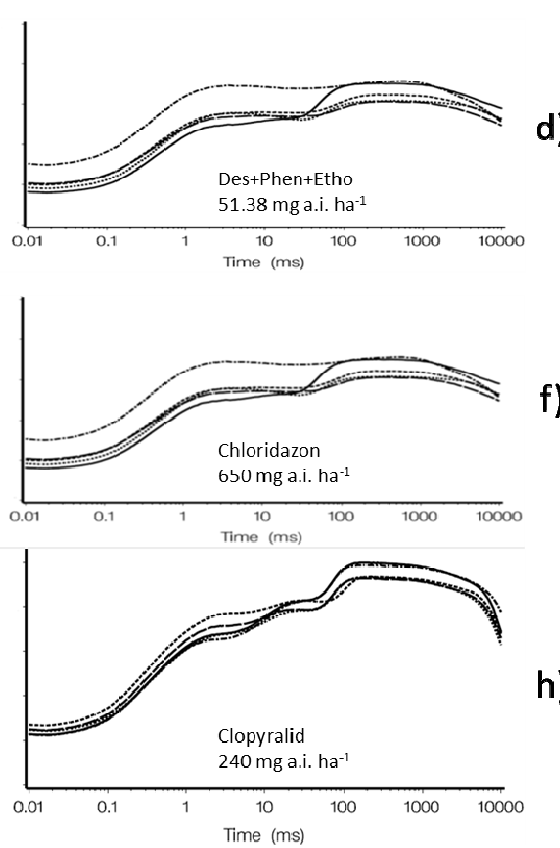

\section{h)}

Fig. 2. Effect of herbicides application on the shape of the Kautsky curve. Kautsky curve for untreated plants of Amaranthus retroflexus (a) and Portulaca oleracea (b), Des + Phen + Etho effects on A. retroflexus (c) and P. oleracea (d) at $51.38 \mathrm{mg}$ a.i. ha ${ }^{-1}$. Chloridazon effects on A. retroflexus (e) and P. oleracea (f) at 326 and $650 \mathrm{mg}$ a.i. ha ${ }^{-1}$ respectively, $A$. retroflexus $(\mathrm{g})$ affected and $P$. oleracea $(\mathrm{h})$ unaffected at $240 \mathrm{mg}$ a.i. ha ${ }^{-1}$ by clopyralid. Each curve is the mean of twelve replications for untreated controls and four replications for rest of the doses. Des + Phen + Etho $=$ Desmedipham + phenmedipham + ethofumesate; HAS value is mean hours after spraying. 
to almost horizontal lines by desmedipham + phenmedipham + ethofumesate for all doses in $P$. oleracea at 24, 48 and 72 HAS in the second experiment (Fig. 2d). By increasing the dose of the desmedipham + phenmedipham + ethofumesate at a lag time of 168 HAS, the OJIP steps of the Kautsky curve were interrupted and it seems this lag period was not suitable for fluorescence measuring due to the death of the plants with fluorescence virtually ceasing in $P$. oleracea (Fig. $2 \mathrm{~d}$ and $3 \mathrm{~b}$ ). Chloridazon did not affect the reduction of $P$. oleracea florescence in any interval at doses of $81.25,162.5$ and $325 \mathrm{~g}$ a.i. ha ${ }^{-1}$ compared to the control treatment, while the Kautsky curves were altered to almost horizontal lines at other doses of 650$2600 \mathrm{~g}$ a.i. ha ${ }^{-1}$ by chloridazon (Fig. 2f). Clopyralid did not well influence the Kautsky curves at any hours of florescence measurement and the administration of doses in $P$. oleracea (Fig. 2h).

\section{The fluorescence parameters}

Several parameters were derived from the shape of the Kautsky curve in response to herbicide doses, and most of them were probably logically correlated. The most common ones to indicate the dose-response of the tested herbicides were $F_{V} / F_{m}, F_{V_{j}}$ and area. The value of the $F_{V} / F_{m}$ parameter which basically is a scaled measurement of the magnitude of the variable fluorescence from the $\mathrm{O}$ to the $\mathrm{P}$ steps, was close to 0.83 in all plants and consistent during the experimental
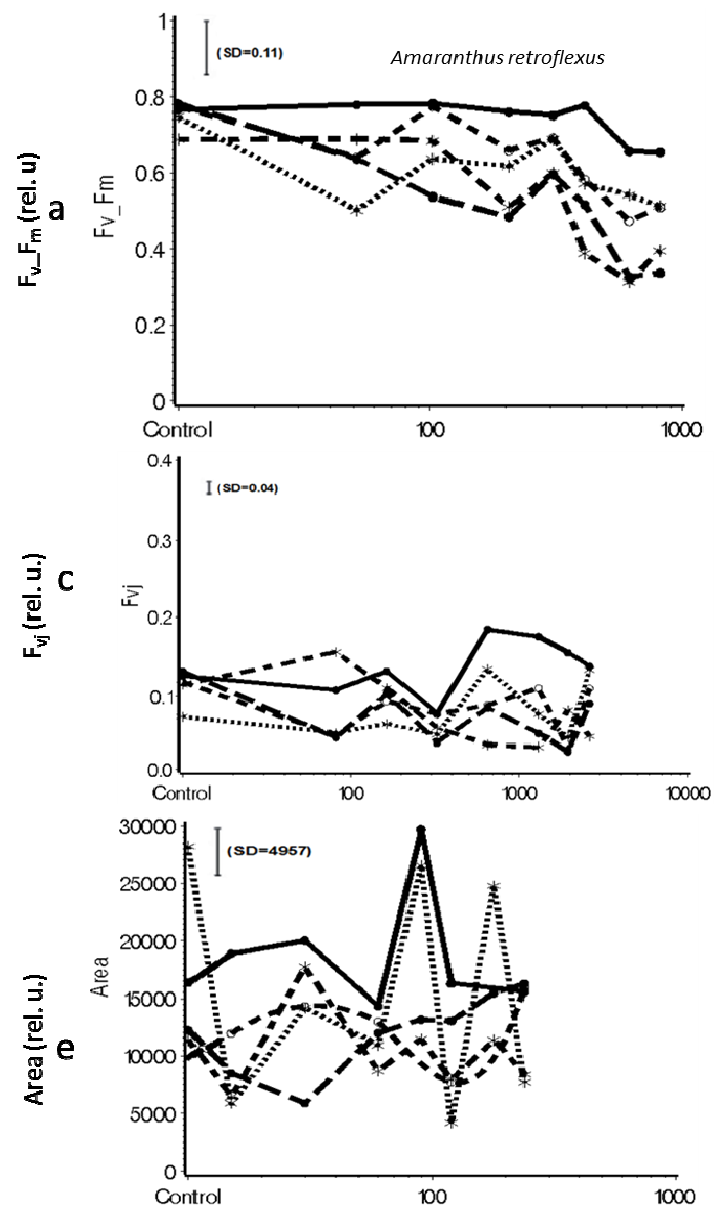

Fig. 3. Effect of desmedipham + phenmedipham + ethofumesate on $F_{\mathrm{v}} / F_{\mathrm{m}}$ in Amaranthus retroflexus (a) and Portulaca oleracea (b), chloridazon effect on $F_{\mathrm{vj}}$ in $A$. retroflexus (c) and $P$. oleracea (d) and clopyralid effect on area in $A$. retroflexus (e) and $P$. oleracea (f). HAS: hours after spraying, SD: standard deviation period, while $\mathrm{F}_{\mathrm{Vj}}$ and the area fluctuated to some extent during the course of the study (Fig. 1) (Abbaspoor et al., 2006). The detailed changes of fluorescence parameters in treated plants are shown in Fig. 3 for both experiments. In $A$. retroflexus, $\mathrm{F}_{\mathrm{V}} / \mathrm{F}_{\mathrm{m}}$ was a steady $4 \mathrm{HAS}$ and reduced at other time intervals by desmedipham + phenmedipham + ethofumesate while $\mathrm{F}_{\mathrm{Vj}}$ and the area were dramatically lessened. Chloridazon had a slight effect on $\mathrm{F}_{\mathrm{V}} / \mathrm{F}_{\mathrm{m}}$ while $\mathrm{F}_{\mathrm{Vj}}$ and the area obviously showed a downward trend in $A$. retroflexus. In addition, $\mathrm{F}_{\mathrm{V}} / \mathrm{F}_{\mathrm{m}}$ and the area were not influenced by clopyralid in $A$. retroflexus, whereas $\mathrm{F}_{\mathrm{Vj}}$ declined (Fig. 3a,c,e). The application of herbicides show the effect on fluorescence parameters onset 4 HAS in $P$. oleracea. $\mathrm{F}_{\mathrm{V}} / \mathrm{F}_{\mathrm{m}}$ that was affected by using $51.38 \mathrm{mg}^{\text {a.i. }} \mathrm{ha}^{-1}$ of desmedipham + phenmedipham + ethofumesate in $P$. oleracea as its value reached roughly 0.7 . This parameter was deeply impressed and reached 0.5 by using the highest dose (822 mg a.i. ha ${ }^{-1}$ ). Other Kautsky parameter curves such as $\mathrm{F}_{\mathrm{Vj}_{j}}$ and the area were reduced faster by desmedipham + phenmedipham + ethofumesate in $P$. oleracea as those values reached zero. $\mathrm{F}_{\mathrm{V}} / \mathrm{F}_{\mathrm{m}}$ was stabilized by chloridazon in $P$. oleracea, whereas the area decreased following the use of doses up to $1000 \mathrm{~g}$ a.i. ha ${ }^{-1} 72$ and 168 HAS and $F_{\mathrm{Vj}}$ sharply diminished at all doses and time intervals. $\mathrm{F}_{\mathrm{V}} / \mathrm{F}_{\mathrm{m}}$ and the area remained constant even after clopyralid use but $\mathrm{F}_{\mathrm{V}_{j}}$ was considerably reduced (Fig. 3b,d,f).

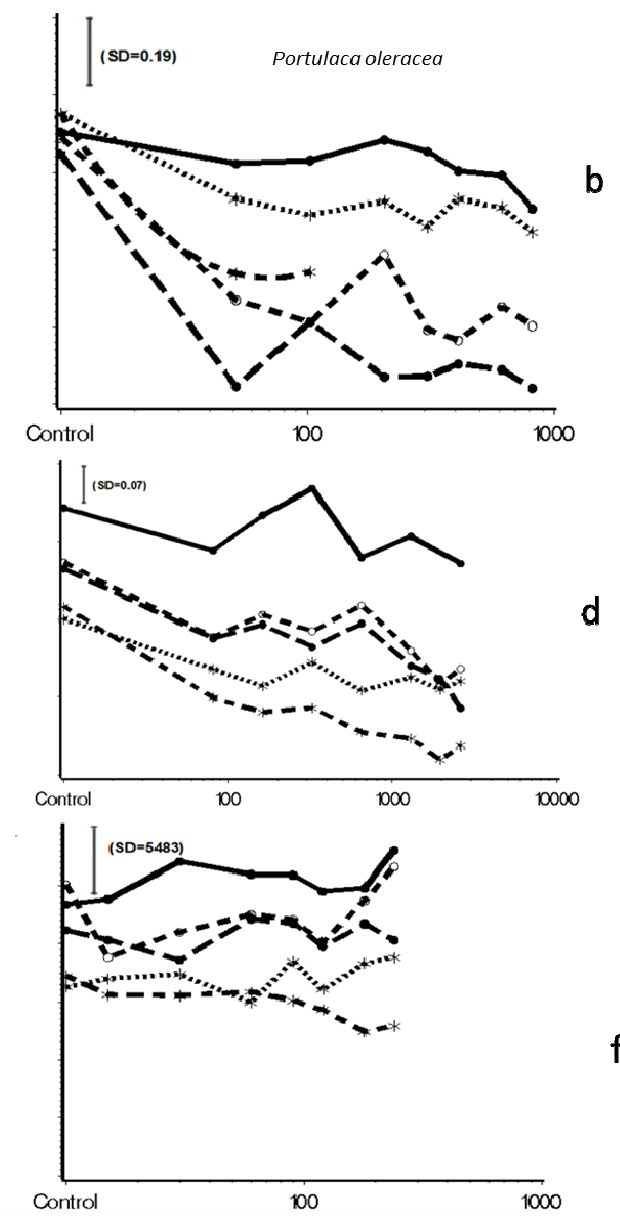


438

The relationship between fluorescence parameters and dose-response curve

The shape of the Kautsky curve changed at J-step $\left(\mathrm{F}_{\mathrm{V}_{\mathrm{i}}}\right)$ following the use all the herbicides including 4 HAS but $\mathrm{F}_{\mathrm{V}} / \mathrm{F}_{\mathrm{m}}$ was poorly affected; however, because $\mathrm{F}_{\mathrm{Vj}}$ probably detects changes in electron transport and thylakoid energization, it might be a useful parameter to show a doseresponse relationship. Percival et al., (1992) previously reported that $\mathrm{F}_{\mathrm{Vj}}$ may cases for dose-response curves interpretation. A summary of the relationship between fluorescence parameter and dose-response curve is shown in Fig. 4a,b,c. The dry weight of $A$. retroflexus and $P$. oleracea all herbicidal treatments well fitted with log logistic threeparameter model. Table (1) shows the values of $\mathrm{ED}_{90}$ estimated for $\mathrm{F}_{\mathrm{v}_{\mathrm{j}}}$ are less than the calculated value of $\mathrm{ED}_{90}$ for dry weight of both species 21 days after treatment (DAS). The lack of the fit test was also not significant in both experiments and showed a good variation in data by a log logistic three-parameter model.
The relationship between fluorescence parameters and $d r y$ weight

The relationship between dry weights, was taken 21 DAS by desmedipham + phenmedipham + ethofumesate and chloridazon, and the selected fluorescence parameters, taken $24 \mathrm{HAS}$ for $A$. retroflexus and $P$. oleracea, respectively (Fig. 5). The slope of the curves is steeper for desmedipham + phenmedipham + ethofumesate compared chloridazon. A linear regression of dry weight on fluorescence parameters was fitted to the data, and the relationship between fluorescence parameters and dry weight was evident. The slope of the curves was steeper for desmedipham + phenmedipham + ethofumesate compared chloridazon. The graphs show four HAS; $\mathrm{F}_{\mathrm{V}} / \mathrm{F}_{\mathrm{m}}$ was more affected by the lipophilic desmedipham + phenmedipham + ethofumesate $\left[\log \left(\mathrm{K}_{\text {ow }}\right)=9.68\right]$ and chloridazon $\left[\log \left(\mathrm{K}_{\text {ow }}\right)=1.19\right]$ than by the hydrophilic clopyralid $\left[\log \left(\mathrm{K}_{\mathrm{ow}}\right)=2.34 \times 10^{-2}\right]$. It also showed that the plants died in the course of the experiment.
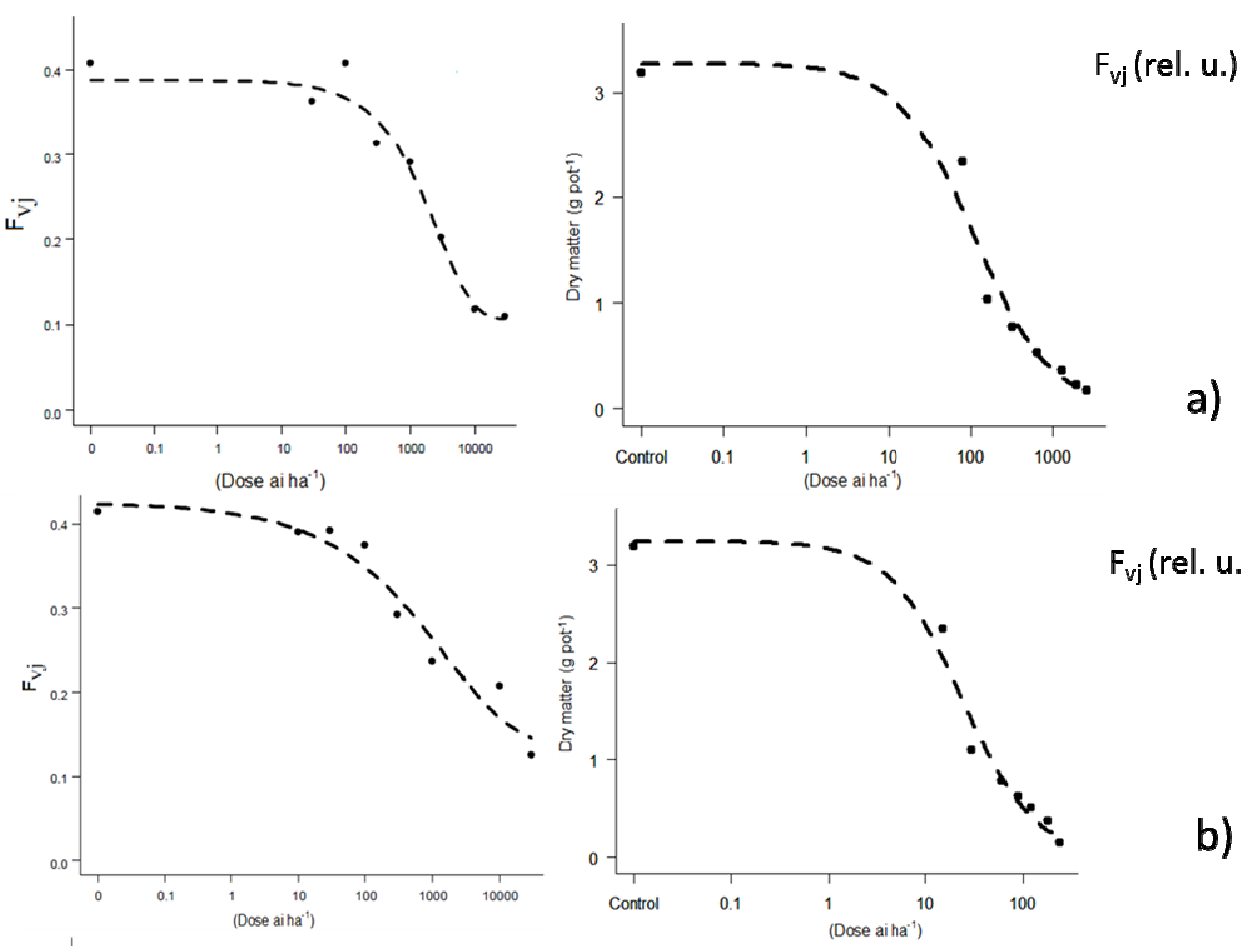

$F_{\text {vj }}$ (rel. u.)
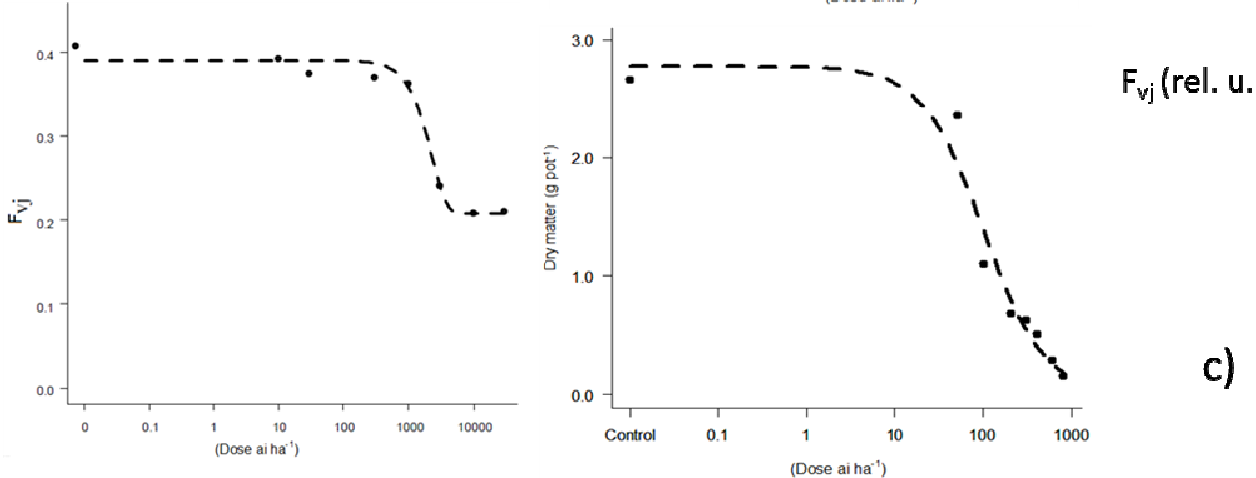

Fig. 4. Dose-response curves for fluorescence $24 \mathrm{~h}$ and dry matter 21 days after treatment of Amaranthus retroflexus with chloridazon (a) (experiment 1); Dose-response curves for fluorescence $24 \mathrm{~h}$ and dry matter 21 days after treatment of $A$. retroflexus with clopyralid (b) (experiment 1); Dose-response curves for fluorescence $24 \mathrm{~h}$ and dry matter 21 days after treatment of Portulaca oleracea with desmedipham + phenmedipham + ethofumesate (c) (experiment 2$)$ 

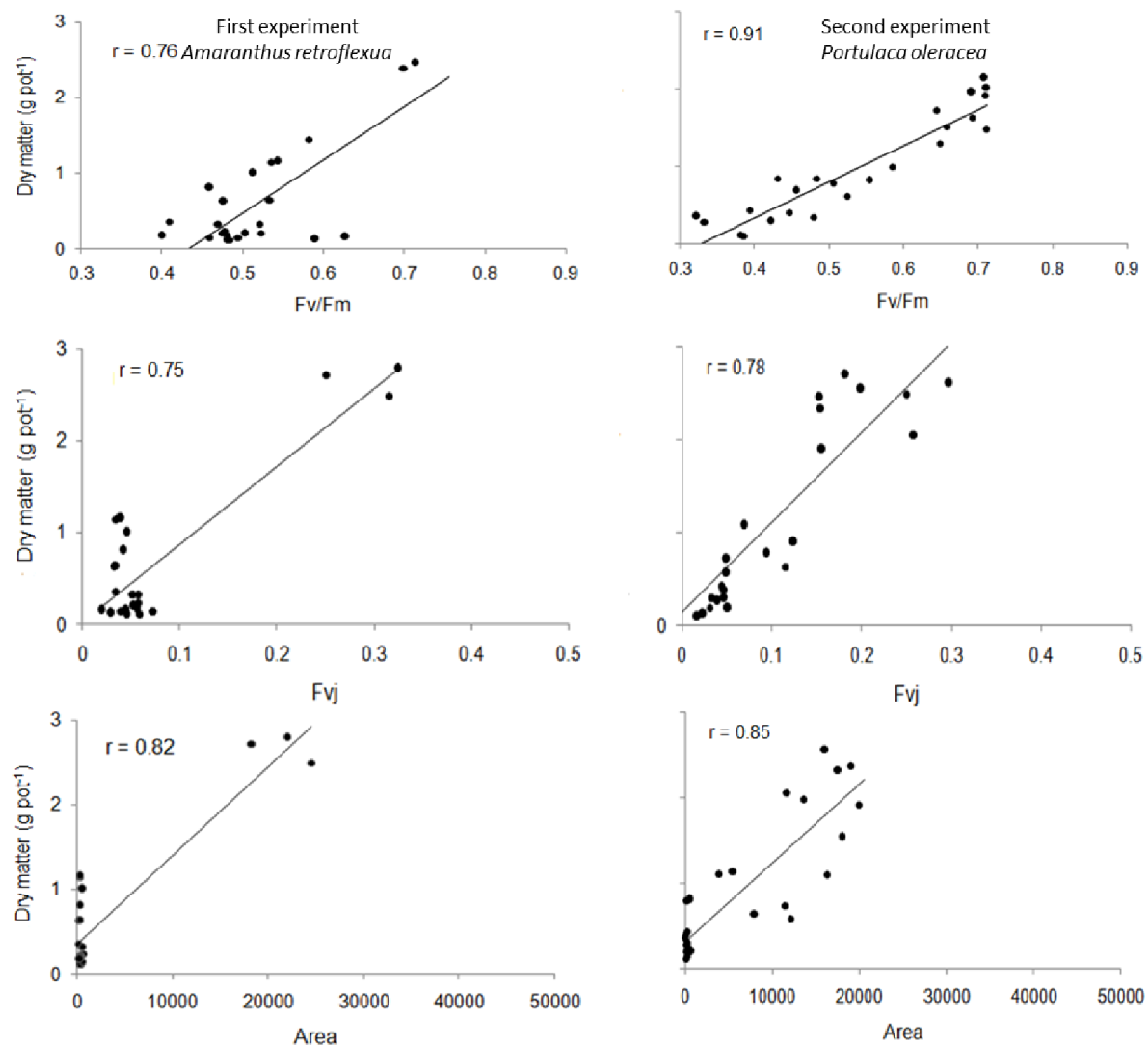

Fig. 5. The relationship between dry matter and chlorophyll fluorescence parameters $\left(F_{V} / F_{m}, F_{V j}\right.$ and area $)$ at $24 \mathrm{~h}$ after spraying [HAS] in two experiments. (Left, Amaranthus retroflexus sprayed by desmedipham + phenmedipham + ethofumesate in the first experiment; right, Portulaca oleracea sprayed by chloridazon in the second experiment).

\section{Discussion}

Our results indicated that desmedipham + phenmedipham + ethofumesate was more potent compared to chloridazon and clopyralid. Between species, the effects of applied herbicides were severe on $P$. oleracea control than $A$. retroflexus. Zhang et al. (1997) demonstrated that photosynthetic inhibitors such as bentazon had an excellent performance on $P$. oleracea control. Fennimore and Rachuy (2005) reported that desmedipham/ phenmedipham and ethofumesate applications provided acceptable control of $P$. olerace and $A$. retroflexus. Starke and Renner (1996); Bosak et al., (2001) and Abdollahi and Ghadiri (2004) reported that phenmedipham plus desmedipham showed a much better weeds control in sugar beet than phenmedipham alone. The reason for discrepancies among $\mathrm{ED}_{\mathrm{x}}$ value of herbicides could be ascribed to the different phenological stages of a plant, climatic conditions and plant species and the period of treatment. Abbaspoor and Streibig (2007) and Chitband et al. (2015) reported that different $\mathrm{ED}_{\mathrm{x}}$ such as
$\mathrm{ED}_{50}$ or $\mathrm{ED}_{90}$ derived from log-logistic dose-response curves may be due to different stages of plant growth at the time of the herbicide treatment, and weed species as well as climatic differences under greenhouse conditions. Abbaspoor and Streibig $(2005,2007)$ depicted that the inhibition of photosynthesis by desmedipham and phenmedipham is raised in the high post-spray light intensity than low light intensities. Bellinder et al. (2003) pointed out that successful control using herbicide rates depended critically on current environmental conditions. Therefore, it appears that the different $\mathrm{ED}_{50}$ or $\mathrm{ED}_{90}$ values caused by desmedipham + phenmedipham + ethofumesate, chloridazon and clopyralid were due to the variation in light and temperature conditions of both species. This is illustrated by the relative potency between the herbicides (Table 1).

In spite of desmedipham + phenmedipham + ethofumesate effect on the shape of the Kautsky curve was obviously strong 4 HAS, while the oxidation state in dark adapted leaves by chloridazon and clopyralid was incomplete in PSII. As soon as radiation saturated light of 
440

PSII centres were completely reduced, the maximum fluorescence at $\mathrm{P}$ step $\left(\mathrm{F}_{\mathrm{m}}\right)$ was emitted in leaves. The fluorescence of treated leaves increased from the groundstate value $\left(F_{0}\right)$ but it could not reach its maximum value $\left(\mathrm{F}_{\mathrm{m}}\right)$. Therefore, this reaction resulted in the reduction of an area. The chlorophyll fluorescence was decreased after $P$ by using 51.38 and 325-650 $\mathrm{mg}$ a.i. $\mathrm{ha}^{-1}$ by desmedipham + phenmedipham + ethofumesate and chloridazon, respectively in both species but it did not occur in the $P$. oleracea by clopyralid. The lack of fluorescence decay following this period suggests that PSII were damaged and PSII-mediated fluorescence quenching did not take place (Fig. 1). In the presence of PSII inhibitors, excitation energy generated by P680 cannot be dissipated by a normal electron flow further than $\mathrm{Q}_{\mathrm{A}}$, resulting in a dramatic increase in fluorescence yield, leading to the production of reactive oxygen species (Cobb and Reade, 2010). Finally, cell membranes and tissues disintegrate due electron transport chain reaction of free-radical attack (Cobb and Reade, 2010). This phenomenon was observed in case of many PSII inhibitors by a large number of researchers (Habash et al., 1985; Van Heerden et al., 2003; Christensen et al., 2003; Abbaspoor et al., 2006; Chitband et al., 2015; Thach and Truong, 2016). These transformations in the shape of the Kautsky curve were irreversibly affected by the PSII inhibitor (Fig. 1).

On the other hand, herbicide activities on the fluorescence parameters could depend on the contrasting compound properties. Desmedipham + phenmedipham + ethofumesate and chloridazon have a direct impact on photosynthesis efficacy because of having a $\log \left(\mathrm{K}_{\mathrm{ow}}\right)$ of 9.68 and 1.19 respectively, whilst clopyralid with $\log \left(\mathrm{K}_{\text {ow }}\right)$ $2.34 \times 10^{-2}$ and solubility in aqueous solvents (polar solvent) did not. Horgan and Zabkiewicz (2008) showed that the performance of photosynthesis in plants exposed to herbicides was determined by $\log \left(\mathrm{K}_{\mathrm{ow}}\right)$ of herbicides.

In addition, the discrepancy among herbicides performance was affected by weed species at the time of treatment. According to the results, $P$. oleracea due to its spongy leaves and branches was not influenced by clopyralid (a plant growth regulator) at the maximum dose of $240 \mathrm{mg}$ a.i. ha ${ }^{-1}$. Zhang et al. (1997) reported that P. oleracea was resistant to PGR herbicides like 2,4-D and was tolerant to ALS inhibitor herbicides like imazethapyr. In contrast, clopyralid affected $A$. retroflexus at the same dosage (Fig. 2g). Previous studies indicated that the shape of Kautsky curves had been affected by non-PSII herbicides in Avena sativa L. (Abbaspoor and Streibig, 2005), Sinapis arvensis L. (Avarseji et al., 2012) and Solanum nigrum L. (Chitband et al., 2015). The reason of growth inhibition by clopyralid in susceptible weeds may be attributed to growth inhibition by the ethylene evolution (Cobb and Reade, 2010), ceasing the biosynthesis of abscisic acid (ABA) (Grossmann et al., 2001), stomatal closure, restriction of $\mathrm{CO}_{2}$ diffusion through stomata (Cronic, 2000), accumulation of reactive oxygen species (ROS) mainly $\mathrm{H}_{2} \mathrm{O}_{2}$, and the leakage of $\mathrm{O}_{2}$ in the chloroplast (Dat et al., 2000). $\mathrm{H}_{2} \mathrm{O}_{2}$ generated by hydroxyl radicals resulted in lipid peroxidation and oxidative damage (Dat et al., 2000). Subsequently, thylakoid membrane electron leakage and oxidative damage of thylakoid phospholipid membrane of the chloroplasts interrupt the electron transport side chain from PSII to PSI and this interruption of the $Z$ scheme will change the shape of the Kautsky curves (Dayan and Zaccaro, 2012; Balabanova et al., 2016).

Desmedipham + phenmedipham + ethofumesate and chloridazon in both weeds and clopyralid in $A$. retroflexus changed the shape of the Kautsky curves at J step $\left(\mathrm{F}_{\mathrm{vj}}\right)$. Therefore, we may conclude that this parameter explains a dose-response relationship and detects changes in the electron transport chain (Christensen et al., 2003). Abbaspoor and Streibig (2005) showed that the logistic dose-response curve need not be applied to fluorescence responses, even though it showed the response of the biomass to the herbicide dose to be within acceptable limits (Table 1). Among different variables derived from the Kautsky curves, $F_{V} / F_{m}$ was relatively stable, whereas $F_{v j}$ and area reduced in both species. Abbaspoor and Streibig (2007) stated that the relative changes at the J step $\left(\mathrm{F}_{\mathrm{vj}}\right)$ had proven to be useful parameters in discerning the effects of herbicides with different modes of action. Other studies, used the relationship between the fluorescence parameter and the dry weight for the PSII inhibitor such as desmedipham, phenmedipham or a mixture of both for Beta vulgaris L. and S. nigrum L. (Abbaspoor and Streibig, 2007; Chitband et al., 2015), metamitron and terbuthylazine for B. vulgaris L. (Abbaspoor et al., 2006), bentazone in $S$. alba L. and B. vulgaris L. (Christensen et al., 2003) and ametryn in Echinochloa colona L. (Elahifard et al., 2013). The use of these fluorescence parameters may suggest a rapid, noninvasive and cost-effective option to eliminate the need for whole plant bioassay screenings.

\section{Conclusions}

In conclusion, based on experimental evidence and available information, classical screening methods can be replaced by chlorophyll fluorescence studies. Among the various fluorescence parameters used to describe the effect of the PSII inhibitors on different plant species, we focus on common fluorescence parameter for three tested herbicides including $\mathrm{F}_{\mathrm{V}} / \mathrm{F}_{\mathrm{m}}, \mathrm{F}_{\mathrm{Vj}}$ and area. The findings of this study revealed that $\mathrm{F}_{\mathrm{V}} / \mathrm{F}_{\mathrm{m}}$ was less sensitive to detecting changes in the Kautsky curve while $\mathrm{F}_{\mathrm{Vj}}$ and area observed responsive parameters for evaluating the effect of herbicide soon after spraying. So the use of the chlorophyll fluorescence method may enhance the herbicide bioassay studies in the future. In this method, the analysis of the Kautsky curve could enable a weed scientist to discern early interruption of the electron transport side chain from PSII to PSI. So chlorophyll fluorescence method could be used for a variety of herbicide groups at different action sites. Finally, the link between dry weight and the fluorescence parameters may be used to shorten the screening experiment time for PSII and nonPSII inhibitors.

\section{Acknowledgements}

This work was performed in partial fulfilment of requirements for the Ph.D. degree (Project No. 3/23529) in Weed Science at Ferdowsi University of Mashhad that was financed by a grant from the College of Agriculture. 


\section{References}

Abbaspoor M, Streibig JC (2005). Clodinafop changes the chlorophyll fluorescence induction curve. Weed Science 53(1):1-9.

Abbaspoor M, StreibigJC (2007). Monitoring the efficacy and metabolism of phenylcarbamates in sugarbeet and black nightshade by chlorophyll fluorescence parameters. Pest Management Science 63(6):576-585.

Abbaspoor M, Teicher HB, StreibigJC (2006). The effect of root-absorbed PSII inhibitors on Kautsky curve parameters in sugar beet. Weed Research 46(3):226-235.

Abdollahi F, Ghadiri H(2004). Effect of separate and combined applications of herbicides on weed control and yield of sugar beet. Weed Technology 18(4):968-976.

Andersen RN (1968). Germination and establishment of weeds for experimental purposes. Weed Science Society of America Handbook, UrbanaIL pp 26-27.

Appenroth KJ, Stockel J, Srivastava A, Strasser RJ (2000). Multiple effects of chromate on the photosynthesis apparatus of Spirodela polyrhiza as probed by OJIP chlorophyll A fluorescence measurements. Environmental Pollution 115(1):49-64.

Avarseji Z, RashedMohassel MH, Nezami A, Abbaspoor M, NassiriMahallati M (2012). Dicamba +2,4D affects the shape of the Kautsky curves in wild mustard (Sinapis arvensis). Plant Knowledge Journal 1(2):41-45.

Balabanova DA, Paunov M, Goltsev V, Cuypers A, Vangronsveld J, Vassilev A (2016). Photosynthetic performance of the imidazolinone resistant sunflower exposed to single and combined treatment by the herbicide imazamox and an amino acid extract. Frontiers in Plant Science 7:1-10.

Barbagallo RP, Oxborough K, Pallett KE Baker NR (2003). Rapid, noninvasive screening for perturbations of metabolism and plant growth using chlorophyll fluorescence imaging. Plant Physiology 132(2):485493.

Bellinder RR, Arsenovic M, Shah DA, Rauch Source BJ (2003). Effect of weed growth stage and adjuvant on the efficacy of fomesafen and bentazon. Weed Science 51:1016-1021.

Boisvert S, Joly D, Carpentier R (2006). Quantitative analysis of the experimental O-J-I-P chlorophyll fluorescence induction kinetics. The FEBS Journal 273(20):4770-4777.

Bosak P, Lajos K, Lajos M (2001). Phytotoxicity studies in sugar beet. Novenytermeles 50:61-69.

Chitband AA, Ghorbani R, Rashed Mohassel MA, Abbasi R(2015). Effect of photosystem II, lipid biosynthesis and auxin inhibitor herbicides on fluorescence induction curve. Australian Journal of Crop Science 9(9):826-834.

Christensen MG, Teicher HB, Streibig JC (2003). Linking fluorescence induction curve and biomass in herbicide screening. Pest Management Science 59(12):1303-1310.

Cobb AH, Reade JPH (2010). Herbicides and Plant Physiology, $2^{\text {th }}$ ed. Wiley-Blackwell, WestSussex, New York.

Cornic G (2000). Drought stress inhibits photosynthesis by decreasing stomatal aperture- not affecting ATP synthesis. Trends in Plant Science 5(5):187-188.

Dat J, Vandenabeele S, Vranova E, Van Montagu M, Inze D, Van
Breusegem F (2000). Dual action of the active oxygen species during plant stress responses. Cellular and Molecular Life Sciences CMLS 57(5):779-795.

Dayan FE, Zaccaro ML (2012). Chlorophyll fluorescence as a marker for herbicide mechanisms of action. Pesticide Biochemistry and Physiology 102(3):189-197.

Elahifard E, Ghanbari A, Rashed Mohassel MH, Zand E, Mirshamsi A, Abbaspoor M (2013). Measuring chlorophyll fluorescence parameters for rapid detection of ametryn resistant junglerice (Echinochloa colona (L.) Link.). Plant Knowledge Journal 2:76-82.

Fennimore SA, Rachuy SJ (2005). Screening of pre-plant incorporated, preand post-emergence herbicides in leafy vegetables, leafy greens, and herbs. Department of Plant Sciences, University of California-Davis, Salinas, CA, 93905 .

Govindjee A (1995). Sixty-three years since Kautsky-chlorophyll-a fluorescence. Australian Journal of Plant Physiology 22:131-160.

Grossmann K, Kwiatkowski A, Tresch S (2001). Auxin herbicides induce $\mathrm{H} 2 \mathrm{O} 2$ overproduction and tissue damage. Journal of Experimental Botany 52(362):1811-1816.

Habash D, Percival MP, Baker NR (1985). Rapid chlorophyll fluorescence technique for the study of penetration of photosynthetically active herbicides into leaf tissue. Weed Research 25(5):389-395.

Hess FD (2000). Light-dependent herbicides: an overview. Weed Science 48(2):160-170.

Holub O, Seufferheld MJ, Gohllke C, Govindjee, Heiss GJ, Clegg RM (2007). Fluorescence lifetime imaging microscopy of Chlamydomonas reinhardtii: non-photochemical quenching mutants and the effect of photosynthetic inhibitors on the slow chlorophyll fluorescence transient. Journal of Microscopy 226(2):90-120.

Horgan DB, Zabkiewicz JA (2008). Fluorescence decline ratio: comparison with quantum yield ratio for plant physiological status and herbicide treatment response. New Zeeland Plant Protection 61:169-173.

Juneau Ph, Qiu B, Deblois CP (2007). Use of chlorophyll fluorescence as a tool for determination of herbicide toxic effect: Review. Toxicological and Environmental Chemistry 89(4):609-625.

Kim JS, Jung S, HwangIT, Cho KY (1999). Characteristics of chlorophyll a fluorescence induction in cucumber cotyledons treated with Diuron, Norflurazon, and Sulcotrionem. Pesticide Biochemistry and Physiology 65(2):73-81.

Kohno H, Ohki A, Ohki S (2000). Low resistance against novel 2 benzylamino-1,3,5- triazine herbicides in atrazine resistant Chenopodium album plants. Photosynthesis Research 65(2):115-120.

Luo XY, Sunohara Y, Matsumoto H (2004). Fluazifop-butyl causes membrane peroxidation in the herbicide-susceptible broadleaf weed bristly starbur (Acanthospermum hispidum). Pesticide Biochemistry and Physiology78(2):93-102.

Maxwel IK, Johnson GN (2000). Perspectives in experimental botany. Chlorophyll fluorescence-Apractical guide. Journal of Experimental Botany 51(345):659-668.

Misra AN, Srivastava A, Strasser RJ (2001). Utilisation of fast Chlorophyll a fluorescence technique in assessing the salt/ion sensitivity of mung bean and brassica seedlings. Journal of Plant Physiology 158(9):1173-1181. 
442

Papageorgiou GC, Govindjee G (2004). Chlorophyll a Fluorescence: A Bit of Basics and History. In: Chlorophyll a Fluorescence. A Signature of Photosynthesis (Advances in Photosynthesis and Respiration). Springer, Dordrecht, The Netherlands pp 1-41.

Percival MP, Baker NR (1991). Herbicides and photosynthesis. Herbicides. London pp 1-26.

Percival MP, Blowers MH, Green JW, Baker NR (1992). Chlorophyll fluorescence- a noninvasive technique for rapid investigation of the effects of adjuvants on herbicide and plant growth regular uptake by leaves. In: Foy CF (Eds). Adjuvants for Agrichemicals. CRC Press, London UKpp 187-193.

Ritz C, StreibigJC (2012). Dose response curves and other non-linear curves in Weed Science and Ecotoxicology with the add-on package drc in R. Retrieved 27 May 2017 from www. bioassay. Dk.

Rodriguez R, Strasser R (2002). The Laboratory of Bioenergetics. University of Geneva, Switzerland. Retrieved 15 February 2017 from http://www.unige.ch/sciences/biologie/bioen/main1.html.

Seefeldt SS, Jensen JE, Fuerst E (1995). Log-logistic analysis of herbicide dose-response relationships. Weed Technology 9(2):218-227.

Srivastava A, Strasser RJ, Govindjee (1999). Greening of peas: Parallel measurements of $77 \mathrm{~K}$ emission spectra, OJIP chlorophyll a fluorescence transient, period four oscillation of the initial fluorescence level, delayed light emission, and P700. Photosynthetica 37:365-392.

Starke RJ, Renner KA (1996). Velvetleaf (Abutilon theophrasti) and sugar beet (Beta vulgaris) response to triflusulfuron and desmedipham plus phenmedipham. Weed Technology 10:121-126.
Strasser RJ, Govindjee (1992). The Fo and the OJIP fluorescence rise in higher plants and algae. In: Argyroudi-Akoyunoglou JH (Ed). Regulation of Chloroplast Biogenesis. Plenum Press, New York USA pp 423-426.

Streibig JC, Rudemo M, Jensen JE (1993) Herbicide bioassay: Doseresponse curves and statistical models. In: Streibig JC, Kudsk P (Eds). Herbicide Bioassays. CRC Press, Boca Raton, FL pp 29-55.

Thach BLE, Truong QB (2016). Quick assessment of the invasiveness of non-native plant species by using eco-physiological parameters in Tram Chim National Park, Vietnam. Weed Biology and Management 16(4):177-185.

Van Heerden PDR, Tsimilli-Michael M, Kruger GHJ, Strasser RJ (2003). Dark chilling effects on soybean genotypes during vegetative development: parallel studies of $\mathrm{CO} 2$ assimilation, chlorophyll a fluorescence kinetics O-J-I-P and nitrogen fixation. Physiologia Plantarum 117(4):476-491.

ZhangJH, Guo SJ, Guo PY, Wang X (2014). The interacting effect of urea and fenoxaprop-P-ethyl on photosynthesis and chlorophyll fluorescence in Perilla frutescens. Photosynthetica 52(3):456-463.

Zhang WM, McGiffen JME, BeckerJO, Ohr HD, Sims JJ, Kallenbach RL (1997). Dose response of weeds to methyl iodide and methyl bromide. Weed Research 37(3):181-189. 